\title{
A retrospective study of anthrax on the Ghaap Plateau, Northern Cape province of South Africa, with special reference to the 2007-2008 outbreaks
}

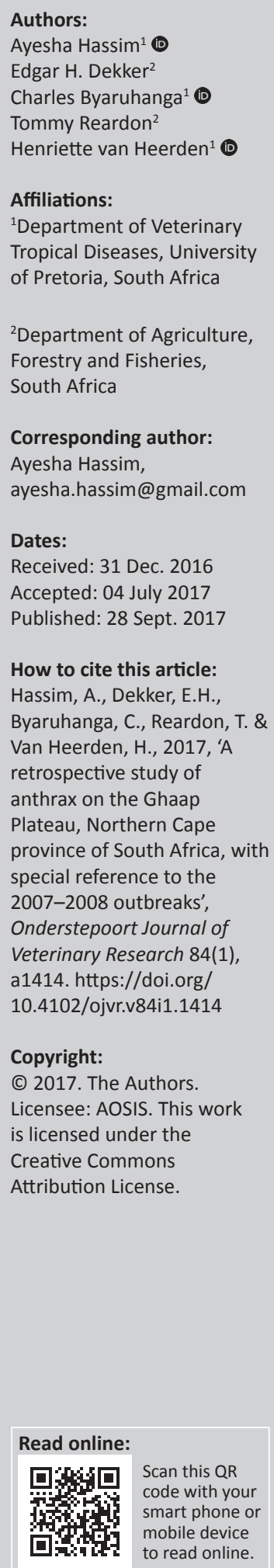

Anthrax is a zoonotic disease caused by the gram-positive, endospore-forming and soil-borne bacterium Bacillus anthracis. When in spore form, the organism can survive in dormancy in the environment for decades. It is a controlled disease of livestock and wild ungulates in South Africa. In South Africa, the two enzootic regions are the Kruger National Park and the Ghaap Plateau in the Northern Cape province. Farms on the Plateau span thousands of hectares comprising of wildlife - livestock mixed use farming. In 2007-2008, anthrax outbreaks in the province led to government officials intervening to aid farmers with control measures aimed at preventing further losses. Because of the ability of the organism to persist in the environment for prolonged periods, an environmental risk or isolation survey was carried out in 2012 to determine the efficacy of control measures employed during the 2007-2008, anthrax outbreaks. No $B$. anthracis could be isolated from the old carcass sites, even when bone fragments from the carcasses were still clearly evident. This is an indication that the control measures and protocols were apparently successful in stemming the continuity of spore deposits at previously positive carcass sites.

\section{Introduction}

The Northern Cape province (NCP) is in South Africa, situated $30^{\circ} \mathrm{S}, 22^{\circ}$ E. It is the largest province in South Africa spanning $372889 \mathrm{~km}^{2}$. A dolomitic escarpment elevates the mid-eastern border of the province, extending $275 \mathrm{~km}$ to the south west, known as the Ghaap Plateau (Partridge et al. 2010; Smit 1978). The province is divided into two ecological areas, namely the Savannah Biome in the north-eastern half of the province while the south-western half hosts the rare and more arid Nama Karoo Biome (Fourie \& Roberts 1973). The province contains a number of state, provincial and privately owned wildlife conservancy areas. The NCP also services the Kgalagadi Transfrontier Park bordering Botswana and the Richtersveld Transfrontier Park bordering Namibia (http:/ / www.sanparks.co.za/conservation). Because of this predominating savannah in the eastern part of the province, the majority of the remaining land is utilised for extensive farming of sheep, cattle and mixed farming which includes wild game (http://www.southafrica.info/ about/geography/northern-cape.htm).

The NCP has alkali, phosphorus deficient soils which lead to pica in grazers and browsers in the form of osteophagia and geophagia (Boyazoglu 1973; De Vos \& Turnbull 2004; Theiler 1912). This animal behavioural characteristic has resulted in a variety of infections with similar pathologies of which 'lamsiekte' (botulism, Clostridium botulinum, 'miltsiekte' (anthrax, Bacillus anthracis) and 'stijfsiekte' (Three Day Sickness, rhabdovirus) are amongst the most common (Theiler 1912; Viljoen, Curson \& Fourie 1928). Both anthrax and botulism are caused by soil-borne, spore-forming and toxin-producing bacteria. Carcasses are typically observed to have an opisthotonic form with oedema or protruding of the tongue for both diseases (Edmonds 1922; Theiler 1912; Van der Lugt et al. 1995). Anthrax and botulism have been observed to occur on the same farm, even simultaneously at times and this has been a cause for misdiagnosis in the past (Kriek \& Odendaal 1994; Theiler 1912, 1927; Viljoen et al. 1928).

Anthrax is an acute or peracute zoonotic disease predominantly affecting livestock and wild ungulates with episodic spill over to humans and carnivores. It is characterised by oedema, sudden death syndrome, black eschars and haemorrhaging from the orifices (Turnbull 2008). The disease is caused by the gram-positive, aerobic and endospore-forming bacterium B. anthracis. Vegetative B. anthracis cells have a distinct encapsulated, square ended 'box-shaped' appearance 
on Giemsa stained blood smears (Hugh-Jones \& De Vos 2002; Turnbull 2008), which is a means of distinguishing them from other gram-positive rod shaped bacteria microscopically (Theiler 1912). The use of selective media and morphological selection are typically employed for bacteriologic isolation of B. anthracis followed by testing for sensitivity to Gamma phage and penicillin as well as verification of virulence factors as added confirmation for the bacterium and differentiation from closely related Bacillus cereus sensu lato group organisms (Knisely 1966; Turnbull 1999).

Infection of a host can be through ingestion, inhalation or cutaneous. Once an infected animal has died, its carcass becomes a potential site of infection for the next host (Dragon et al. 2005). Anthrax is an World Organisation for Animal Health (OIE) reportable disease and opening of carcasses is strictly prohibited (Turnbull 2008). Sporulation is triggered by nutrient shortages and exposure to oxygen (Sterne 1937; Turnbull 2008). Bacterial spore counts are higher where bloody discharge from the orifices and bodily fluids from the carcass soak the ground (Bellan et al. 2013). Sporulation also takes place when a carcass is opened by scavengers such as vultures (Gyps spp./Trigonoceps occipitalis/Torgos tracheliotos), crows (Corvus spp.), jackal (Canis spp.) or hyena (Crocuta crocuta) (Hugh-Jones \& De Vos 2002; Turnbull 2008). Blowflies are considered as mechanical vectors of anthrax in the Kruger National Park (KNP) because they feed on a carcass and then deposit $B$. anthracis laden regurgitate on vegetation around the carcass. This contaminated vegetation may then be a potential source of infection to susceptible kudus (Tragelaphus strepsiceros) and other browsers or grazers (Blackburn et al. 2014; Braack \& De Vos 1990; De Vos \& Turnbull 2004; Hugh-Jones \& De Vos 2002). Spores in the environment have been recovered by De Vos (1990) from bones during archaeological excavations at a site in KNP that were estimated to be $200 \pm 50$ years old.

To reduce such spore inoculum in the environment incineration of anthrax carcasses and burial have been the preferred method and in accordance with WHO and OIE guidelines internationally (Turnbull 2008). Treating anthrax carcasses with $10 \%$ formalin would kill the bacteria, deter scavengers that would open the carcass and decrease spread by flies, but remains controversial because of the health and safety issues related to its handling. Turnbull (2008) also proposed covering or wrapping carcasses in plastic or tarpaulins to keep the skin intact and reduce vegetative Bacilli through putrefaction and thus anthrax spores in the environment. Other control methods include covering the carcass in thorns to deter animals from eating at the site, as well as the use of insecticides to inhibit the role of flies and carrion insects on the carcass (Williams \& Barker 2008; Williams \& Richardson 1984).

The two anthrax-enzootic areas in South Africa (Figure 1) are the NCP and KNP (Bengis et al. 2002; De Vos \& Turnbull 2004; Hugh-Jones \& De Vos 2002; Smith et al. 2000). While mandatory vaccination schemes have virtually abolished anthrax in livestock in most of the country, these areas remain

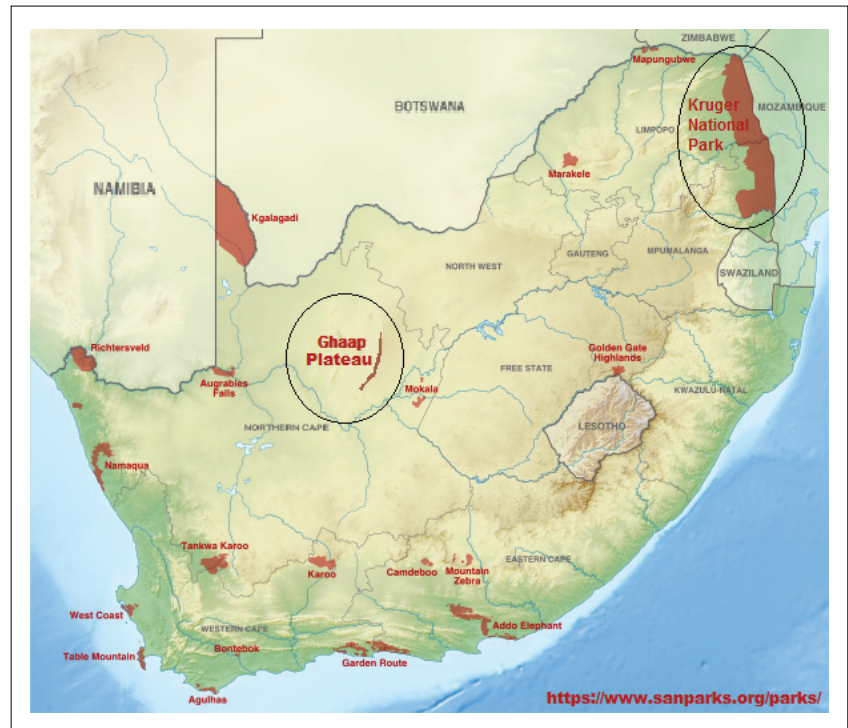

Source: SANparks, http://www.sanparks.org

FIGURE 1: A modified map of South Africa detailing the National Parks. The two circled areas represent the anthrax-enzootic areas (Kruger National Park and the Ghaap Plateau).

enzootic because of the predominance of wildlife conservancies and game farms (Gilfoyle 2006; Turnbull 2008). A large number of animals usually succumb to the disease before it is noticed because of the short incubation period and the large areas involved. Kudus are typical fatalities of anthrax, but in 2008 large numbers of antelope and equids were also affected in the NCP outbreaks. The outbreak gained momentum from 2007, and by the end of March 2008, had resulted in the deaths of thousands of heads of game and economic losses to the farmers of the Ghaap Plateau amounting to millions of South African rand (Visagie 2008). It was the largest recorded outbreak in the region in recent history and the Department of Agriculture Fisheries and Forestry in South Africa mobilised national and provincial state veterinary services to aid in diagnosis, surveillance and control measures in order to stem the outbreaks (Nduli 2009; Visagie 2008). The aims of this study were (1) to report the $2007 / 2008$ B. anthracis outbreaks in the NCP, (2) to determine the $B$. anthracis spore concentrations from bone and environmental samples during the 2007-2008 NCP anthrax outbreaks using bacteriological methods and (3) to compare the spore concentrations from bone and soil collected at the same sites in 2012 to determine the spore endurance and/or efficacy of the control measures employed during the $2007 / 2008$ outbreaks in reducing the inoculum in the environment.

\section{Materials and methods \\ Observations, sample collection and control measures during 2007-2008 anthrax outbreaks}

The first cases of the 2007-2008 anthrax outbreaks in NCP were reported in November 2007 at Doringbult farm (Figure 2) after heavy spring rainfall during mid-August - November 2007. Later that month, the skeletal remains of one female kudu (NC/17) on Grootsalmonsfontein and two female kudus (NC/27 and NC/28) on the adjacent farm Dikbosch 


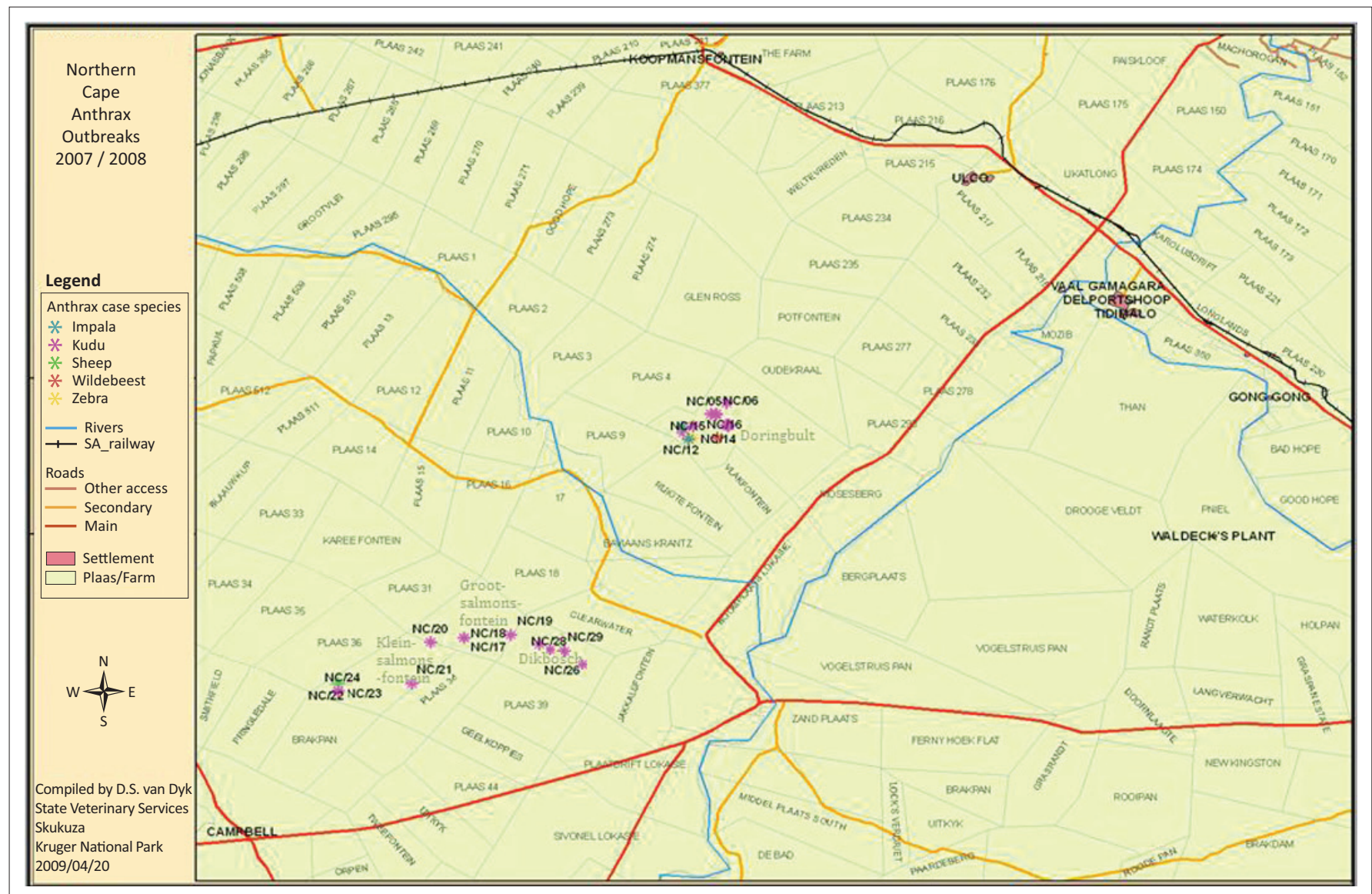

Source: Skukuza State Veterinary Services (Dawid Schalk van Dyk)

FIGURE 2: Anthrax-positive carcass sites indicating the distribution of susceptible species discovered on farms during the 2007-2008 anthrax outbreaks in the Ghaap Plateau in the Northern Cape province, South Africa.

were recovered, all of which were gestating (EH Dekker pers. comm., February 2013; Nduli 2009). The first isolated cases of anthrax from kudu were identified in the latter farm Dikbosch (Figure 2). In February 2008, five more kudu carcasses (both males and females) were discovered on Dikbosch and Kleinsalmonsfontein farms and by the following month anthrax cases included zebra, wildebeest, impala, sheep and kudu along the length of the Ghaap escarpment (Figure 2).

After a kudu at Doringbult was confirmed suspicious for anthrax from a Giemsa stained blood smear, more comprehensive samples were collected for diagnostics. KNP (Skukuza Veterinary Services) and Northern Cape province Veterinary Services visited farms to aid farmers in the diagnosis and control of the outbreak. The condition of the carcasses was documented along with collection of blood smear and bone samples (mandibular, orbital, rib, vertebra, femur and/or pelvic bones if possible). Soil samples were collected from under the head, abdomen and tail of the carcass for diagnostic purposes. Environmental samples such as crow faeces and bone fragments were collected from carcass sites where evidence of scavenger activity was visible (Table 1). Louse flies (Hippobosca rufipes) were observed and collected from recently dead kudu carcasses at Clearwater and Klipfontein (Table 1, Figure 3a). Random soil samples were also collected from farms at the top of the plateau and pans at the base of the escarpment to determine spore counts in areas not contaminated by fresh carcasses (Table 1).

Control measures included vaccination of livestock; treatment of the carcass sites which involved spraying either $10 \%$ chlorine or $10 \%$ formalin on the carcasses; burning of the carcasses and covering up each animal with black plastic or tarpaulins to increase bacterial vegetative cell death and limit blowfly and scavenger access to the carcass. Table 1 indicates the farms affected by the outbreak based on Giemsa stained blood smears as well as carcass condition and observable blowfly, louse fly and crow activity around carcasses.

\section{Collection of soil and bone samples in 2012 from the 2007-2008 anthrax outbreaks carcass sites}

In March 2012, samples were collected at each of the anthrax positive sites from farms, along the Ghaap Plateau, which suffered losses in 2007-2008 (Table 2). Figure 4 indicates the sites visited. Soil samples were also collected from gravel pits, river and stream beds as well as dry pans where water concentrates after rain. The soil sampling followed the topography (water movement) of the land and thus included areas not sampled in 2008 in the search for concentrator sites (see Figure 1-A1 using the topography of Doringbult game farm as an example). Bone samples were taken at sites where bones were available. About 10 of the 48 sites visited yielded bones from the 2007-2008 outbreaks because the black plastic 
TABLE 1: Anthrax-positive carcasses (based on Giemsa stained blood smears) and environmental samples collected from farms along the Ghaap Plateau in the Northern Cape province, South Africa, during outbreaks in 2007-2008 indicating control measures implemented by farm owners and State Veterinary Services.

\begin{tabular}{|c|c|c|c|c|c|c|c|c|}
\hline $\begin{array}{l}\text { Sample } \\
\text { (Processing } N^{\circ} \text { ) }\end{array}$ & Location & Species & Sex & Age & Date & Actions and observations & Latitude & Longitude \\
\hline NC/01 & Doringbult & Kudu & Male & 18 Months & Apr. 2008 & Covered with tarp. & NR & NR \\
\hline $\mathrm{NCP} / 33$ & $\begin{array}{l}\text { Random Soil Sample taken at } \\
\text { the highest and lowest point } \\
\text { of the Doringbult farm } \\
\text { 'drainage basin' }\end{array}$ & - & - & - & - & - & -28.491415 & 24.05425667 \\
\hline $\mathrm{NC} / 02$ & Doringbult & Impala & Male & 18 Months & Apr. 2008 & Covered with tarp. & -28.50074333 & 24.05014667 \\
\hline $\mathrm{NC} / 03$ & Doringbult & Kudu & Male & 12 Months & Apr. 2008 & $\begin{array}{l}\text { Covered with tarp but only put } \\
\text { over a few days after animal's } \\
\text { death. }\end{array}$ & -28.49014167 & 24.04442 \\
\hline $\mathrm{NC} / 04$ & Doringbult & Kudu & Female & Adult & Apr. 2008 & $\begin{array}{l}\text { Covered with tarp. Head was } \\
\text { open. Visible hole in abdomen. }\end{array}$ & -28.48999 & 24.04443833 \\
\hline $\mathrm{NC} / 05$ & Doringbult & Kudu & Female & Adult & Apr. 2008 & $\begin{array}{l}\text { Covered with tarp. Head was } \\
\text { open. }\end{array}$ & NR & NR \\
\hline NC/06 & Doringbult & Kudu & Female & Adult & Apr. 2008 & $\begin{array}{l}\text { Covered with tarp. Unopened. } \\
\text { Only soil was collected. }\end{array}$ & -28.49002333 & 24.04442333 \\
\hline $\mathrm{NC} / 07$ & Doringbult & Kudu & Male & Adult & Apr. 2008 & $\begin{array}{l}\text { Covered with tarp. Consumed by } \\
\text { blowflies. Blowflies collected. }\end{array}$ & -28.48682833 & 24.03966833 \\
\hline $\mathrm{NC} / 08$ & Doringbult & Kudu & Female & 12 Months & Apr. 2008 & $\begin{array}{l}\text { Covered with tarp. Carcass still } \\
\text { wet. High number of maggots. }\end{array}$ & -28.48682833 & 24.03966833 \\
\hline NC/09 & Doringbult & Kudu & Female & Adult & Apr. 2008 & $\begin{array}{l}\text { Covered with tarp. Carcass still } \\
\text { wet. Skin partially rotted. High } \\
\text { maggot activity. }\end{array}$ & -28.3038 & 24.02727 \\
\hline $\mathrm{NC} / 10$ & Doringbult & Kudu & Male & Adult & Apr. 2008 & $\begin{array}{l}\text { Covered with tarp. Sprayed with } \\
10 \% \text { chlorine. Carcass still wet. }\end{array}$ & -28.48682833 & 24.03966833 \\
\hline NC/11 & Vlakfontein & Impala & Male & 18 Months & Apr. 2008 & $\begin{array}{l}\text { Covered with tarp. Well covered } \\
10 \% \text { chlorine. No maggots } \\
\text { observed. }\end{array}$ & -28.30417 & 24.00891 \\
\hline $\mathrm{NC} / 12$ & Vlakfontein & Zebra & Male & Adult & Apr. 2008 & $\begin{array}{l}\text { Covered with tarp. Well covered } \\
\text { in } 10 \% \text { chlorine. No maggots } \\
\text { observed. }\end{array}$ & -28.30892 & 24.0118 \\
\hline $\mathrm{NC} / 13$ & Vlakfontein & Kudu & Female & 6 Months & Apr. 2008 & $\begin{array}{l}\text { Covered with tarp. } 10 \% \text { Chlorine } \\
\text { sprayed over and under carcass. }\end{array}$ & -28.30401 & 24.01324 \\
\hline $\mathrm{NC} / 14$ & Vlakfontein & Zebra & Male & Adult & Apr. 2008 & $\begin{array}{l}\text { Covered with tarp. } 10 \% \text { Chlorine } \\
\text { sprayed over and under carcass. }\end{array}$ & -28.30914 & 24.0135 \\
\hline $\mathrm{NC} / 15$ & Vlakfontein & Impala & Male & 24 Months & Apr. 2008 & $\begin{array}{l}\text { Covered with tarp. } 10 \% \text { Chlorine } \\
\text { sprayed over and under carcass. }\end{array}$ & -28.30951 & 24.0115 \\
\hline $\mathrm{NC} / 16$ & Vlakfontein & Wildebeest & Male & Adult & Apr. 2008 & $\begin{array}{l}\text { Covered with tarp. } 10 \% \text { Chlorine } \\
\text { sprayed over and under carcass. }\end{array}$ & -28.30892 & 24.0118 \\
\hline $\mathrm{NCP} / 23$ & Grootsalmonsfontein & Kudu & Female & Adult & Apr. 2008 & $\begin{array}{l}\text { Eyes pecked out. Orbital bone } \\
\text { swabbed and remains burned. }\end{array}$ & -28.76738833 & 23.77385333 \\
\hline $\mathrm{NCP} / 24$ & Grootsalmonsfontein & Kudu & Male & Adult & Apr. 2008 & $\begin{array}{l}\text { Eyes pecked out. Orbital bone } \\
\text { swabbed and remains burned. }\end{array}$ & -28.76600667 & 23.77385333 \\
\hline $\mathrm{NCP} / 25$ & Grootsalmonsfontein & Kudu & Male & Adult & Apr. 2008 & $\begin{array}{l}\text { Eyes pecked out. Orbital bone } \\
\text { swabbed. }\end{array}$ & -28.76672167 & 23.77427333 \\
\hline NC/17 & Grootsalmonsfontein & Kudu & Female & 24 Months & Nov. 2007 & $\begin{array}{l}\text { Complete skeleton treated with } \\
10 \% \text { formalin. No scavenging } \\
\text { apparent. Blowflies collected. }\end{array}$ & NR & NR \\
\hline NC/19 & Grootsalmonsfontein & Kudu & Male & 30 Months & Apr. 2008 & $\begin{array}{l}\text { Eyes pecked out. Orbital bone } \\
\text { swabbed and remains burned. }\end{array}$ & NR & NR \\
\hline $\mathrm{NC} / 20$ & Grootsalmonsfontein & Kudu & Male & Adult & Apr. 2008 & $\begin{array}{l}\text { No crows or evidence of any. Soil } \\
\text { collected. }\end{array}$ & NR & NR \\
\hline $\mathrm{NC} / 18$ & Grootsalmonsfontein & Kudu & Male & 36 Months & Apr. 2008 & $\begin{array}{l}\text { Complete skeleton treated with } \\
10 \% \text { formalin. }\end{array}$ & NR & NR \\
\hline $\mathrm{NC} / 21$ & Kleinsalmonsfontein & Kudu & Female & Adult & Feb. 2008 & $\begin{array}{l}\text { Complete skeleton treated with } \\
10 \% \text { formalin. }\end{array}$ & -28.70745167 & 23.85113 \\
\hline $\mathrm{NC} / 22$ & Kleinsalmonsfontein & Sheep & Female & Adult & Feb. 2008 & Treated $10 \%$ formalin. & -28.68862167 & 23.86334833 \\
\hline $\mathrm{NC} / 23$ & Kleinsalmonsfontein & Kudu & Male & 36 Months & Feb. 2008 & Treated $10 \%$ formalin. & -28.67122667 & 23.88506167 \\
\hline $\mathrm{NC} / 24$ & Kleinsalmonsfontein & Kudu & Female & Adult & Feb. 2008 & $\begin{array}{l}\text { Complete skeleton treated with } \\
10 \% \text { formalin. }\end{array}$ & -28.65584 & 23.90015833 \\
\hline $\mathrm{NC} / 25$ & Dikbosch & Kudu & Male & 12 Months & Feb. 2008 & $\begin{array}{l}\text { Complete skeleton treated with } \\
10 \% \text { formalin. }\end{array}$ & - & - \\
\hline $\mathrm{NC} / 27$ & Dikbosch & Kudu & Female & Adult & Nov. 2007 & $\begin{array}{l}\text { Complete skeleton. Treated with } \\
10 \% \text { formalin. Bone sampled. }\end{array}$ & -28.66751167 & 23.92223833 \\
\hline $\mathrm{NC} / 28$ & Dikbosch & Kudu & Female & Adult & Nov. 2007 & $\begin{array}{l}\text { Complete skeleton. Treated with } \\
10 \% \text { formalin. Bone sampled. }\end{array}$ & -28.66392167 & 23.92101167 \\
\hline $\mathrm{NC} / 29$ & Dikbosch & Kudu & Male & 12 Months & Feb. 2008 & $\begin{array}{l}\text { Complete skeleton. Treated with } \\
10 \% \text { formalin. Bone sampled. }\end{array}$ & NR & NR \\
\hline $\mathrm{NCP} / 27$ & Dikbosch & Impala & Male & Adult & Apr. 2008 & $\begin{array}{l}\text { Carcass unopened. Crow faeces } \\
\text { and soil collected. }\end{array}$ & NR & NR \\
\hline $\mathrm{NCP} / 28$ & Dikbosch & Kudu & Female & Adult & Apr. 2008 & $\begin{array}{l}\text { Carcass unopened. Hippobosca } \\
\text { rufipes flies collected. }\end{array}$ & NR & NR \\
\hline
\end{tabular}

Source: Collated from records of Northern Cape and Skukuza State Veterinary Services, Department of Agriculture, Forestry and Fisheries, South Africa (by authors E.H. Dekker and T. Reardon) $N R$, no records could be recovered. 
TABLE 1 (Continues...): Anthrax-positive carcasses (based on Giemsa stained blood smears) and environmental samples collected from farms along the Ghaap Plateau in the Northern Cape province, South Africa, during outbreaks in 2007-2008 indicating control measures implemented by farm owners and State Veterinary Services.

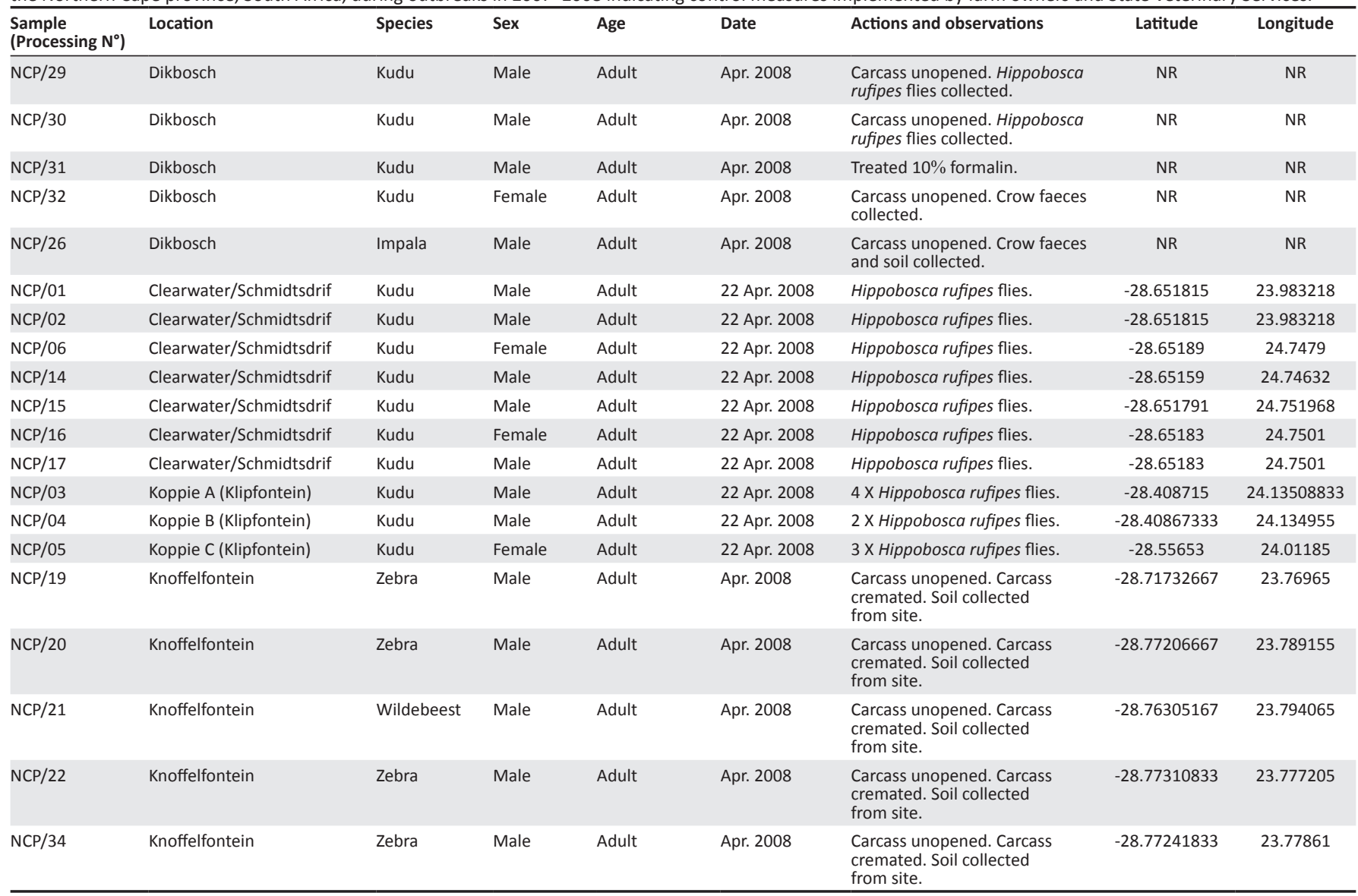

Source: Collated from records of Northern Cape and Skukuza State Veterinary Services, Department of Agriculture, Forestry and Fisheries, South Africa (by authors E.H. Dekker and T. Reardon) NR, no records could be recovered.
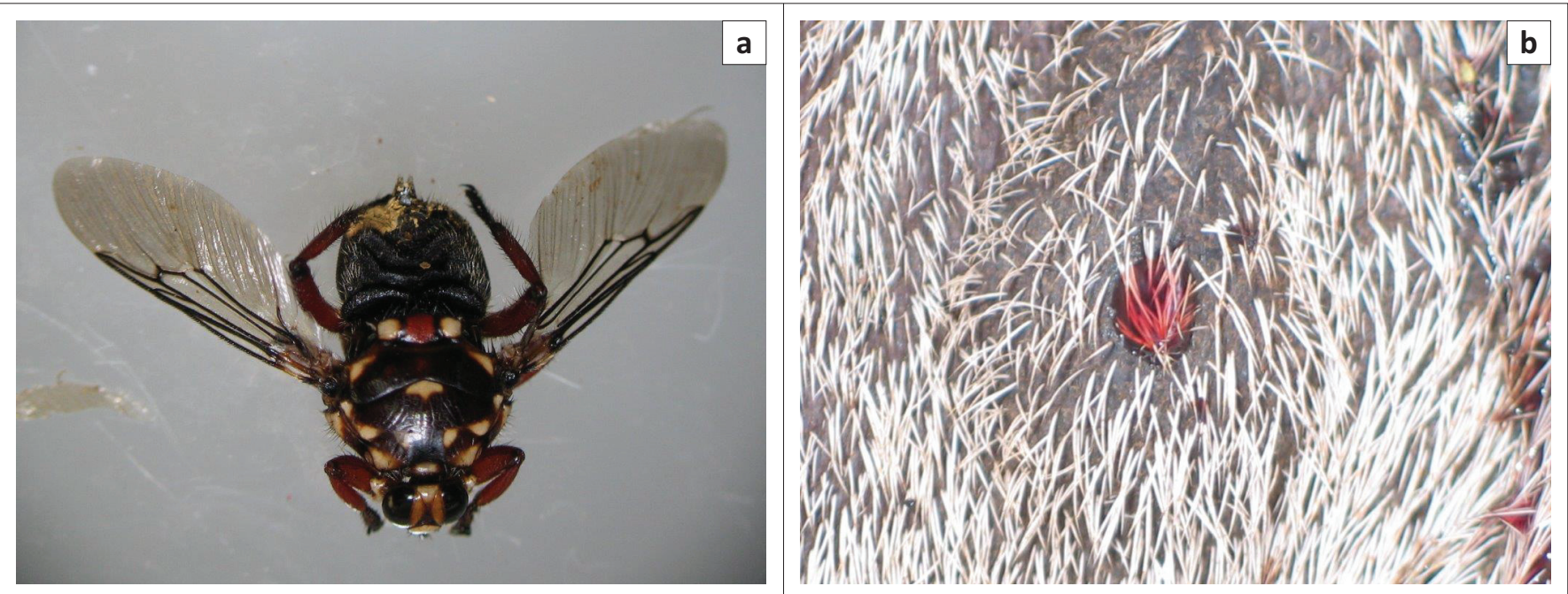

Source: Photos taken by Skukuza State Veterinary Services (by author E.H. Dekker)

FIGURE 3: (a) Louse fly (Hippobosca rufipes) collected from an anthrax-positive carcass from Clearwater, South Africa, during the 2008 outbreaks. (b) Site on anthraxpositive carcass where Hippobosca rufipes had fed.

or tarpaulin remnants or charring from cremation sites were indicators of anthrax cases where control measures were implemented in 2008 (Figure 5). Bacillus anthracis positive controls consisted of two bone samples from the original collection in 2008 (NC/14 and NC/29) that were included as bacteriologic isolation controls.

\section{Bacterial culture}

One gram samples of all soil, crow faeces and ground bone samples were placed in a McCartney bottle with $9 \mathrm{~mL}$ sterile phosphate buffered saline (PBS) and shaken for at least $2 \mathrm{hrs}$. Samples were heat treated at $65{ }^{\circ} \mathrm{C}$ for $25 \mathrm{~min}$ to select for 


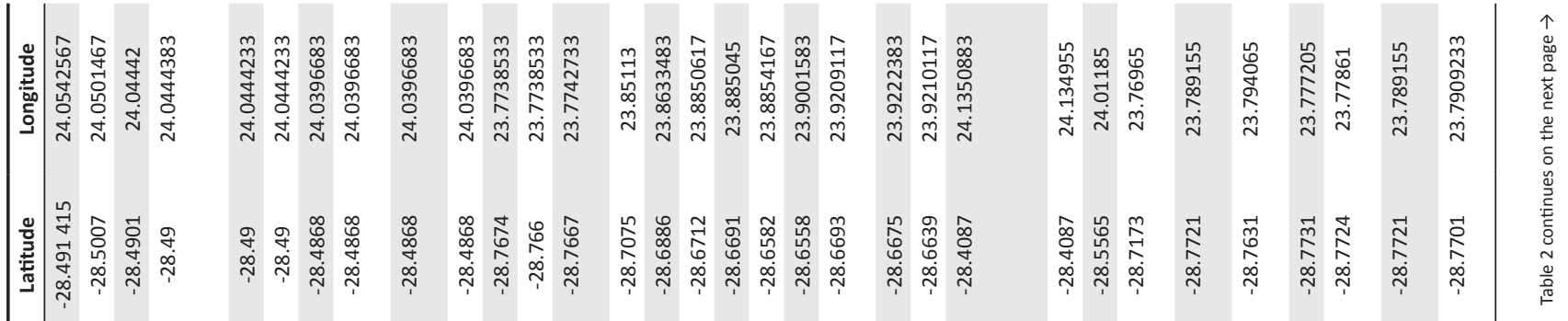

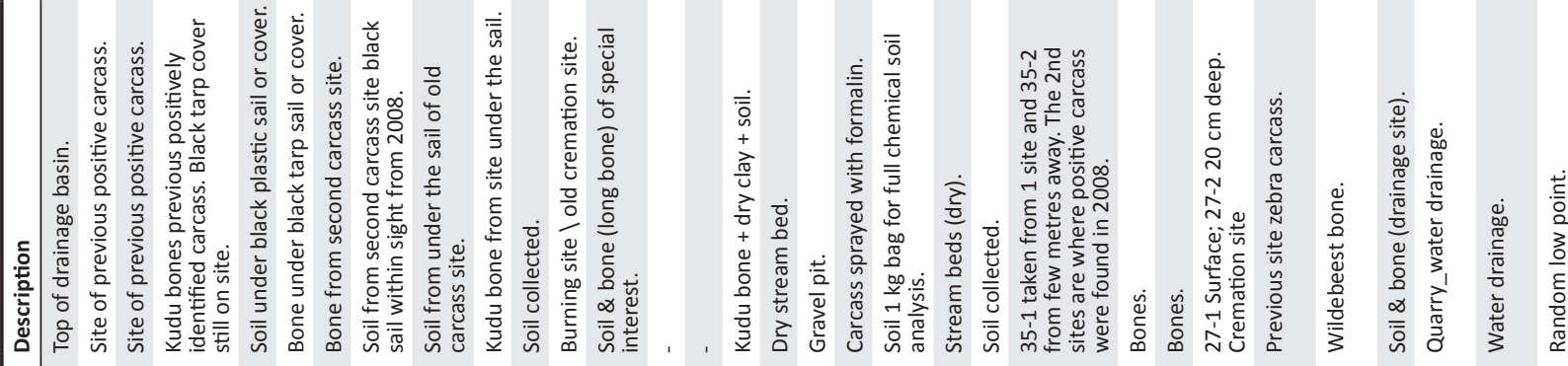

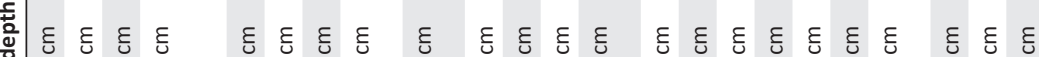

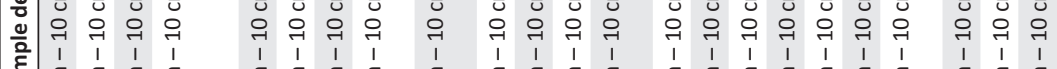

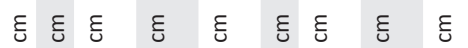

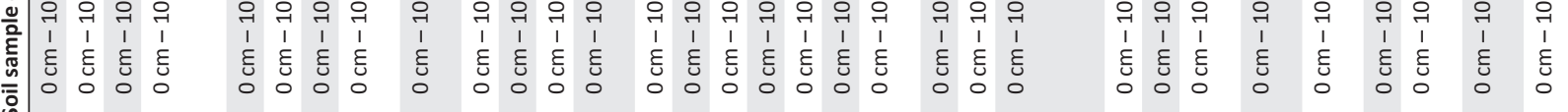

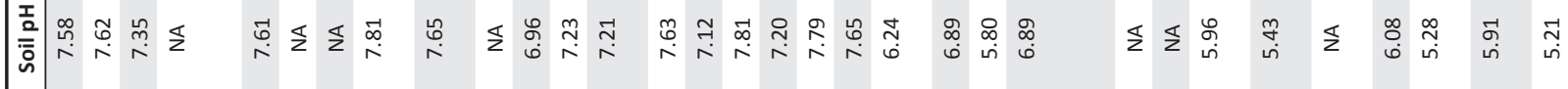

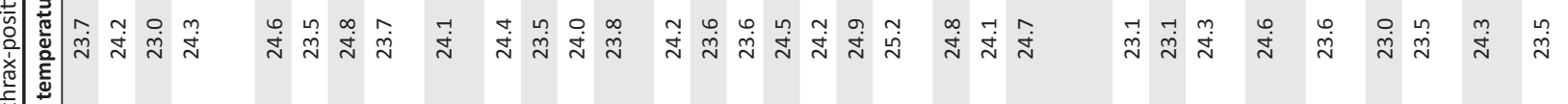

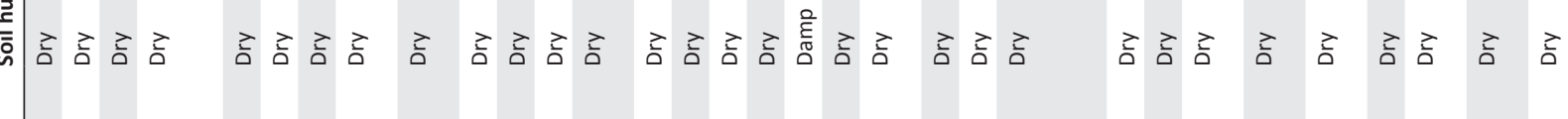

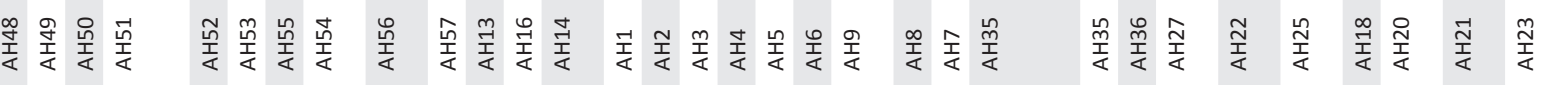

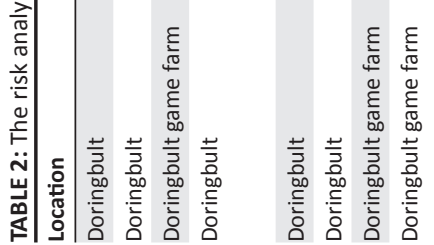

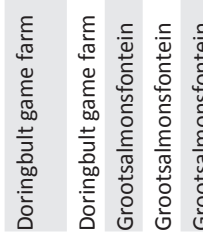




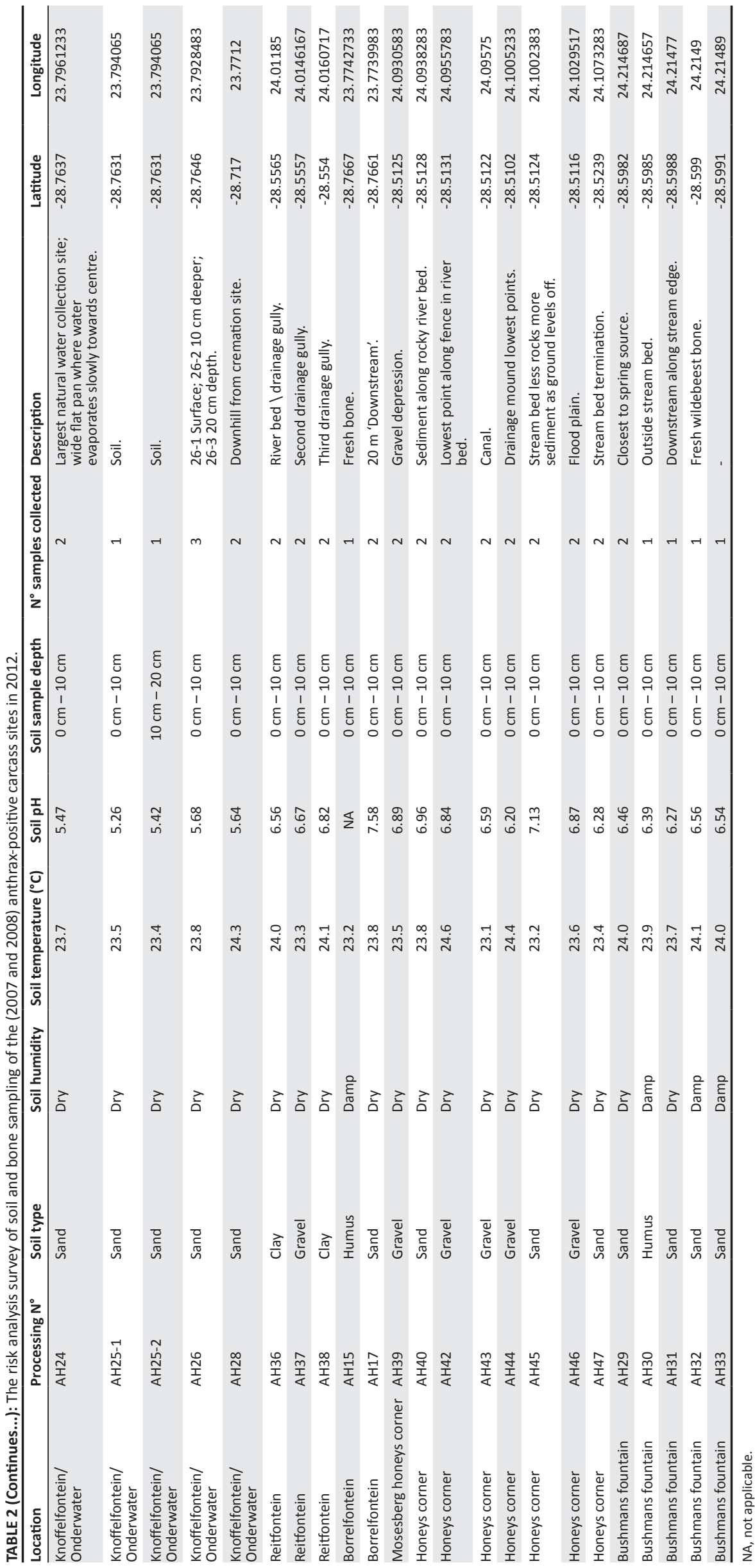




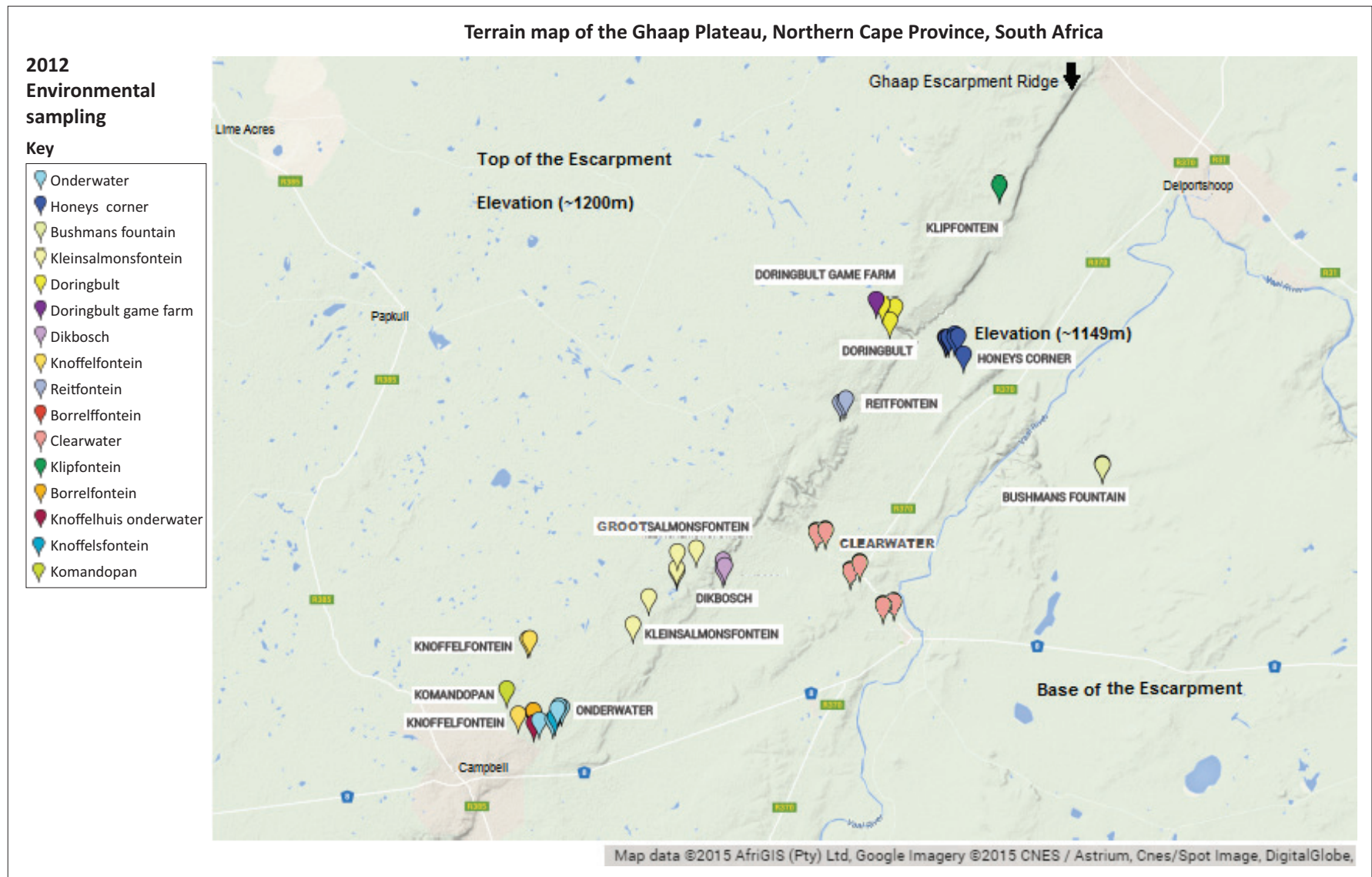

Source: Generated in Google earth V 6.2.2.6613 (http://www.earth.google.com) using data collected during this study

FIGURE 4: Soil and bone samples collected $(n=62)$ in 2012 from farms and carcass sites identified as anthrax-positive by farmers and State Veterinary Services in 2007-2008, South Africa. Additional soil samples were taken along water runoff paths following the Ghaap escarpment drainage topography (indicated as the diagonal ridge line across the map).
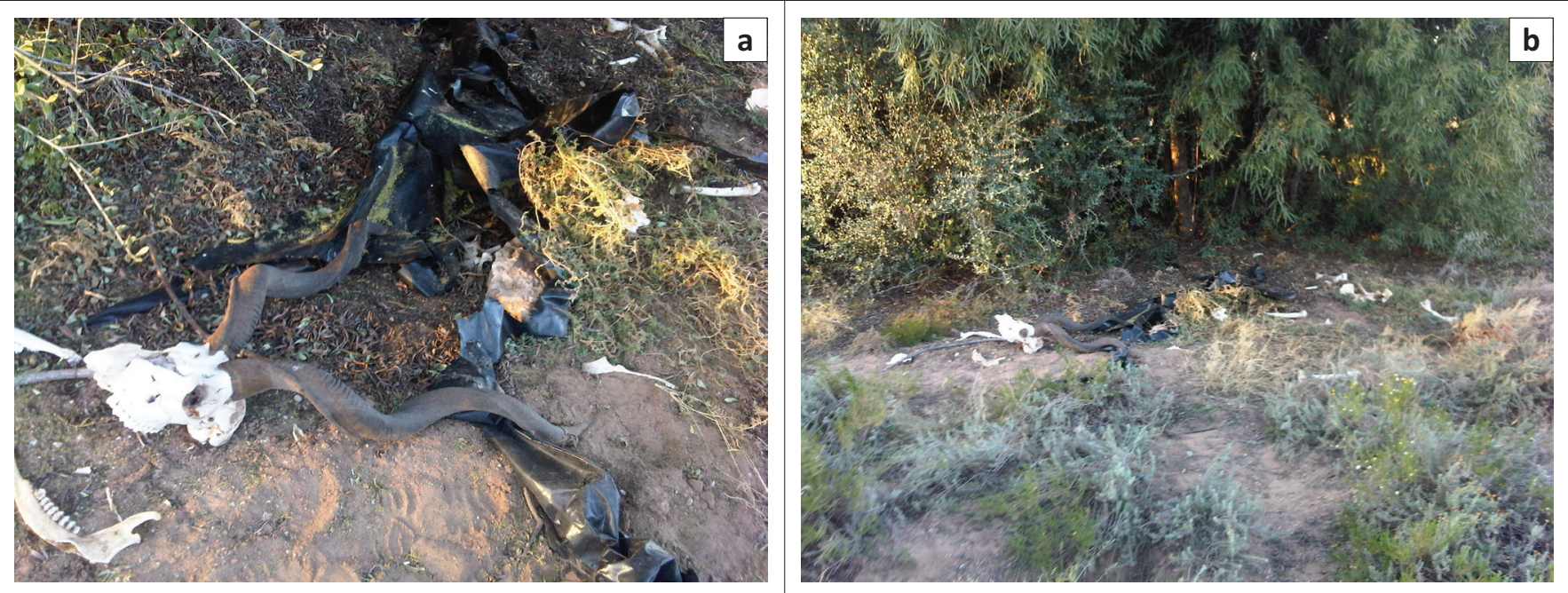

Source: Photos taken by A. Hassim

FIGURE 5: (a) Bones collected in 2012 for isolation of Bacillus anthracis from Doringbult game farm, South Africa (Table 1 samples AH56 and AH57). (b) The black plastic tarp covers and remaining kudu bones were clearly visible at this site which was sprayed with $10 \%$ chlorine before being covered up with the plastic covers in 2008 (Table 1 sample NC/10).

spores. A $100 \mu \mathrm{L}$ of this solution was plated out onto Polymyxin EDTA thallous acetate (PET) agar (PLET agar from Turnbull 2008) where lysozyme was omitted (E.H. Dekker, pers. comm., February 2013) and incubated overnight at $37^{\circ} \mathrm{C}$, then further incubated for $24 \mathrm{hrs}$ when colonies were not apparent. Serial 10-fold dilutions for spore counts were made and plated in triplicate for dilutions of $1 \times 10^{-1}$ to $1 \times 10^{-6}$. The average colony forming units (CFU) of B. anthracis from the 3 plates was calculated. Isolates were confirmed as B. anthracis when sensitive to penicillin and $\gamma$-phage. 
The louse flies' heads were removed and directly plated onto $5 \%$ impala blood agar followed by overnight incubation at $37^{\circ} \mathrm{C}$. All white, non-haemolytic and 'ground glass' domed colonies were tested with penicillin and $\gamma$-phage to confirm B. anthracis. Isolation methods employed in 2012 were exactly the same as those for 2008 with the exception that trimethoprim sulphamethoxazole polymyxin blood agar (TSBPA) (Turnbull 2008) was used in addition to PET and 5\% impala blood agar to maximise isolation success.

\section{Statistical analyses}

A cursory examination of the spore data appeared to highlight a disparity in isolate counts from the various bone samples collected. The spore count data from each bone sample were compared to determine if any trends were apparent. Analysis of variance (ANOVA) was used to evaluate carcass spore counts followed by Tukey's for pairwise comparison test to compare the significance of spore yields between bone samples. Fisher's exact test was used to determine the significance of carcass effect variables such as locality, species, sex and age because of the small sample size.

\section{Results \\ Isolation and spore counts from 2007-2008 outbreaks}

The first reported cases, where bone samples were collected for bacteriologic diagnostics, were on Dikbosch farm (NC/27 and $\mathrm{NC} / 28$ ) with the isolation of $B$. anthracis. Thereafter, bone and soil samples were collected on six other farms in early 2008 (Table 1) where a mean of $6.87 \times 10^{3} \mathrm{cfu} / \mathrm{g}$ and $1.57 \times 10^{3} \mathrm{cfu} / \mathrm{g}$ spores from bone and soil samples, respectively were collected at all 29 carcass sites (Figure 6). A mean of 200 spores was isolated from the heads of the louse flies and 300 spores/g from the crow faeces (Skukuza State Veterinary Services laboratory report). The distribution of carcasses was greater on the top of the escarpment (in terms of carcass dispersal) while being confined to the floodplains at the base of the escarpment (Figure 4). Although the first kudus discovered in 2007 were all female, by the end of the anthrax outbreak, overall twice as many male carcasses were discovered than female carcasses. The numbers of confirmed carcasses were 39 kudus, 6 zebra, 2 impala and 2 wildebeest that died of anthrax. During the collection of samples during the 2007-2008 outbreaks, various control measures were taken to decrease the inoculum of spores in the environment as indicated in Table 1 . These control methods included spraying carcasses with disinfectants, incineration and covering the carcasses in plastic.

Average B. anthracis colony counts from PET and blood agar dilution series plates for the various bone samples can be seen in Figure 6 . The ANOVA evaluation of the spore counts had a significant $p$-value of 0.028 between bone types, whereas the Tukey's pairwise comparison test only showed significance when comparing the femur $(p=0.029)$ and pelvic bones $(p=0.049)$ with the mandibular bone. The mandibular bone generally produced higher spore counts (Figure 6), although, no significance was evidenced by comparison of the mandibular to the rib, vertebrae and orbital bones.

According to Fisher's scoring, the locality of the carcasses was also significant with a $p$-value of 0.022 . The mandibular bone yielded the highest mean spore counts at all localities, with higher counts observed in skeletons or carcasses at Kleinsalmonsfontein followed by Grootsalmonsfontein, Vlakfontein, Doringbult and Dikbosch, respectively (Figure 6; Figure 2-A1). All of these farms are situated on the top of the Ghaap escarpment.

Isolation from the soil under the carcasses at the mouth, abdomen and tail region produced varied spore counts (Table 3). This is reflected in a $p$-value of 0.504 indicating that there is no significance between the sampling location under the abdomen and tail of the carcass (Figure 3-A1). Bacillus anthracis spore counts from the soil under the mouth generally yielded higher spore counts accounting for $61 \%$ of the mean spores isolated from all the farms (Figure 6). There is an agreement of the $B$. anthracis spore counts between the bone and spore counts in the soil at the location of these bones (mouth, abdomen and tail) (Table 3). The mean spore counts under the mouth or head represented $61 \%$ of the total isolated from soil, while the mean spore counts in the mandibular $(45 \%)$ and orbital (21\%) bones together accounted for $66 \%$ of the total isolated. The rib (13\%) with the vertebrae (9\%) made up $22 \%$ of the mean spores isolated from bone versus the soil under the abdomen which represented $21 \%$ of the total soil spores isolated. The femur together with the pelvic bones comprise $12 \%$ of total spores from bone versus the soil collected from under the hind of the animal reflecting 19\% of the mean (Figure 6).

Random soil samples taken from two pans at Doringbult did not yield any $B$. anthracis spores, whereas random samples collected at the lowest points downhill on Doringbult of carcasses NC/01 and NC/04 yielded $5 \times 10^{4}$ and $1.2 \times 10^{4}$ spores per gram of soil on PET agar, respectively (Figure 1-A1). A soil sample collected at Grootsalmonsfontein at the lowest point below carcass NC/18 contained 400 spores per gram of soil.

\section{Isolations in $\mathbf{2 0 1 2}$}

The soil and bone samples collected in 2012, yielded a variety of Bacillus spp. on the different media employed including Bacillus subtilis, B. cereus and Bacillus thuringiensis, but contrary to expectation, no $B$. anthracis was found. The control B. anthracis bone samples NC/14 and NC/29 from the original 2008 outbreaks were positive for the presence of B. anthracis spores as indicated in Table 3. Similar B. anthracis spore counts were obtained in 2008 and 2012 from the reference bone samples NC/14 and NC/29.

\section{Discussion}

The isolation of $B$. anthracis from samples collected in 2007-2008 demonstrates a unique ecology at each carcass site with a variety of vectors such as water, crows, blowflies and 


\begin{tabular}{|c|c|c|c|c|c|c|c|c|c|c|c|c|c|c|}
\hline \multirow[b]{3}{*}{ LAB.No } & \multirow[b]{3}{*}{ Year } & \multirow[b]{3}{*}{ Locality } & \multicolumn{7}{|c|}{ Spore Isolation Results from Bone Samples } & \multicolumn{5}{|c|}{ Spore Isolation Results from Soil Samples } \\
\hline & & & \multirow[b]{2}{*}{ 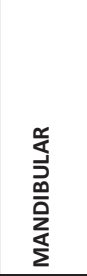 } & \multirow[b]{2}{*}{ 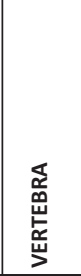 } & \multirow[b]{2}{*}{$\frac{m}{\alpha}$} & \multirow[b]{2}{*}{$\sum_{\underline{u}}^{\varrho}$} & \multirow[b]{2}{*}{$\sum_{\text {号 }}^{\stackrel{n}{\supset}}$} & \multirow[b]{2}{*}{ 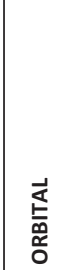 } & \multirow{2}{*}{ 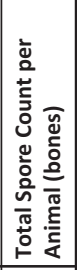 } & Mouth & Abdomen & Tail & \multirow{2}{*}{ 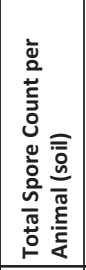 } & \multirow{2}{*}{ 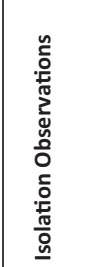 } \\
\hline & & & & & & & & & & $\times 10^{3} \mathrm{CFU} / \mathrm{g}$ & $\begin{array}{l}\times 10^{3} \\
\mathrm{CFU} / \mathrm{g}\end{array}$ & $\begin{array}{l}\times 10^{3} \\
\mathrm{CFU} / \mathrm{g}\end{array}$ & & \\
\hline $\mathrm{NC} / 01$ & 2008 & Doringbult & 4200 & 0 & 0 & 0 & 1430 & 0 & 5630 & oc & OC & OC & 0 & $\mathrm{NOCl}$ \\
\hline $\mathrm{NC} / 02$ & 2008 & Doringbult & 2200 & 2990 & 2650 & 0 & 1810 & 1400 & 11050 & 120 & 41 & oc & 161 & $\mathrm{NOCl}$ \\
\hline NC/03 & 2008 & Doringbult & 150 & 70 & 70 & 0 & 0 & 150 & 440 & OC & OC & $O C$ & 0 & $\mathrm{NOCl}$ \\
\hline NC/04 & 2008 & Doringbult & \begin{tabular}{|l|} 
No \\
sample \\
\end{tabular} & 3200 & 1500 & 0 & 40 & 2800 & 7540 & 1526 & 360 & OC & 1886 & $\mathrm{NOCl}$ \\
\hline NC/05 & 2008 & Doringbult & 25500 & 0 & 1370 & 420 & OC & 14270 & 41560 & 160 & 6 & OC & 166 & $\mathrm{NOCl}$ \\
\hline NC/06 & 2008 & Doringbult & \multicolumn{6}{|c|}{ No sample: carcass was unopened } & 0 & 30 & 1 & $O C$ & 31 & $\mathrm{NOCl}$ \\
\hline NC/07 & 2008 & Doringbult & 230 & 2450 & 2100 & 450 & 20 & 20 & 5270 & 8 & 5,2 & $O C$ & 13,2 & $\mathrm{NOCl}$ \\
\hline $\mathrm{NC} / 08$ & 2008 & Doringbult & \multicolumn{6}{|c|}{$\begin{array}{l}\text { No isolates due to treatment with chlorine } \\
\text { before collection }\end{array}$} & 0 & 4 & 3 & 2 & 9 & \\
\hline $\mathrm{NC} / 09$ & 2008 & Doringbult & 1100 & 20 & 20 & 520 & 250 & 240 & 2150 & 3 & 0,09 & 4 & 7,09 & \\
\hline $\mathrm{NC} / 10$ & 2008 & \begin{tabular}{|l|} 
Doringbult \\
\end{tabular} & 290 & 0 & 0 & 290 & 10 & 730 & 1320 & 10 & 0,6 & 15 & 25,6 & \\
\hline \multicolumn{3}{|c|}{$\begin{array}{l}\text { Total Spore Count per Sample type on Doringbult } \\
\text { Game Farm }\end{array}$} & 33670 & 8730 & 7710 & 1680 & 3560 & 19610 & 74960 & 1861 & 416,89 & 21 & 2298,89 & \\
\hline \multicolumn{3}{|c|}{$\begin{array}{l}\text { Average Spore Count per Sample Type on } \\
\text { Doringbult Game Farm } \\
\end{array}$} & 3367 & 873 & 771 & 168 & 356 & 1961 & 7496 & 186,1 & 41,689 & 2,1 & 229,889 & \\
\hline $\mathrm{NC} / 11$ & 2008 & Vlakfontein & 2800 & 1000 & 2090 & 480 & 230 & 740 & 0 & 115 & 161 & 10 & 286 & \\
\hline $\mathrm{NC} / 12$ & 2008 & Vlakfontein & \multicolumn{6}{|c|}{$\begin{array}{l}\begin{array}{l}\text { No isolates due to treatment with chlorine } \\
\text { before collection }\end{array} \\
\end{array}$} & 0 & \multicolumn{5}{|c|}{$\begin{array}{l}\text { No isolates obtained due to site treatment with chlorine before } \\
\text { collection }\end{array}$} \\
\hline $\mathrm{NC} / 13$ & 2008 & Vlakfontein & 5600 & 3120 & 14000 & 5600 & 10000 & 1270 & 39590 & 6 & 31 & 22 & 59 & \\
\hline $\mathrm{NC} / 14$ & 2008 & Vlakfontein & 25500 & 1870 & 0 & 650 & 0 & 60 & 28080 & 258 & 56 & OC & 314 & $\mathrm{NOCl}$ \\
\hline NC/15 & 2008 & Vlakfontein & 600 & 30 & 870 & 10 & 0 & 70 & 1580 & 10 & 50 & 10 & 70 & \\
\hline $\mathrm{NC} / 16$ & 2008 & Vlakfontein & 1450 & 4900 & 1120 & 1000 & oc & 320 & 8790 & 20 & OC & oc & 20 & NOCl \\
\hline \multicolumn{3}{|c|}{ Total Spore Count per Sample type on Vlakfontein } & 35950 & 10920 & 18080 & 7740 & 10230 & 2460 & 78040 & 409 & 298 & 42 & 749 & \\
\hline \multicolumn{3}{|c|}{$\begin{array}{l}\begin{array}{l}\text { Average Spore Count per Sample Type on } \\
\text { Vlakfontein }\end{array} \\
\end{array}$} & 5991,7 & 1820,0 & 3013,3 & 1290,0 & 1705,0 & 410,0 & 13006,7 & 68,2 & 49,7 & 7,0 & 124,8 & \\
\hline $\mathrm{NC} / 17$ & 2007 & \begin{tabular}{|l} 
Grootsalmon \\
sfontein
\end{tabular} & 2100 & 0 & 0 & 0 & oc & 60 & 2160 & 28 & OC & 24 & 52 & NOCI \\
\hline $\mathrm{NC} / 18$ & 2008 & $\begin{array}{l}\text { Grootsalmon } \\
\text { sfontein }\end{array}$ & 4500 & 0 & 0 & 0 & 0 & 22540 & 27040 & 135 & 10 & 51 & 196 & \\
\hline $\mathrm{NC} / 19$ & 2008 & $\begin{array}{l}\text { Grootsalmon } \\
\text { sfontein }\end{array}$ & 8500 & 160 & 100 & 0 & 490 & \begin{tabular}{|l|l|} 
No \\
sample
\end{tabular} & 9250 & 5 & OC & oc & 5 & NOCl \\
\hline $\begin{array}{l}\text { Total Spo } \\
\text { Grootsalr }\end{array}$ & pe on & & 15100 & 160 & 100 & 0 & 490 & 22600 & 38450 & 168 & 10 & 75 & 253 & \\
\hline $\begin{array}{l}\text { Average } \\
\text { Grootsalr }\end{array}$ & e Type o & & 5033,3 & 53,3 & 33,3 & 0,0 & 163,3 & 7533,3 & 12816,7 & 56,0 & 3,3 & 25,0 & 84,3 & \\
\hline $\mathrm{NC} / 20$ & 2008 & \begin{tabular}{|l}
$\begin{array}{l}\text { Kleinsalmons } \\
\text { fontein }\end{array}$ \\
\end{tabular} & 690 & 160 & \begin{tabular}{|l|}
$\begin{array}{l}\text { No } \\
\text { sample }\end{array}$ \\
\end{tabular} & 10 & 0 & 30 & 890 & 51 & 20 & 50 & 121 & \\
\hline $\mathrm{NC} / 21$ & 2008 & \begin{tabular}{|l|l|}
$\begin{array}{l}\text { Kleinsalmons } \\
\text { fontein }\end{array}$ \\
\end{tabular} & 500 & 0 & 10 & 0 & oc & 330 & 840 & $\begin{array}{l}\text { No isolate obt } \\
\text { collection }\end{array}$ & formalin trea & atment be & fore soil & \\
\hline $\mathrm{NC} / 22$ & 2008 & $\begin{array}{l}\text { Kleinsalmons } \\
\text { fontein }\end{array}$ & $\begin{array}{l}\text { No isolat } \\
\text { collectior }\end{array}$ & $\begin{array}{l}\text { tes due to } \\
\text { in }\end{array}$ & o treatmer & nt with fc & formalin & before & 0 & 50 & 15 & 32 & 97 & OSD \\
\hline $\mathrm{NC} / 23$ & 2008 & \begin{tabular}{|l|} 
Kleinsalmons \\
fontein
\end{tabular} & $\begin{array}{l}\text { No isolat } \\
\text { collectior }\end{array}$ & tes due to & 0 treatmer & nt with fo & formalin $\mathrm{t}$ & before & 0 & 60 & 58 & 90 & 208 & OSD \\
\hline $\begin{array}{l}\text { Total Spo } \\
\text { Kleinsalm }\end{array}$ & pe on & & 1190 & 160 & 10 & 10 & 0 & 360 & 1730 & 161 & 93 & 172 & 426 & \\
\hline $\begin{array}{l}\text { Average } \\
\text { Kleinsalm }\end{array}$ & e Type o & & 297,5 & 40 & 2,5 & 2,5 & 0 & 90 & 432,5 & 40,25 & 23,25 & 43 & 106,6 & \\
\hline $\mathrm{NC} / 24$ & 2008 & Dikbosh & OC & OC & 90 & 0 & 10 & 10 & 110 & OC & OC & $O C$ & 0 & NOCl \\
\hline $\mathrm{NC} / 25$ & 2008 & Dikbosh & OC & 10 & 0 & 0 & 0 & OC & 10 & 87 & 231 & 185 & 503 & \\
\hline $\mathrm{NC} / 26$ & 2008 & Dikbosh & 860 & 0 & 0 & 0 & 0 & 10 & 870 & OC & OC & OC & 0 & NOCl \\
\hline $\mathrm{NC} / 27$ & 2007 & Dikbosh & 3500 & 0 & 20 & 0 & 0 & 0 & 3520 & 60 & 59 & 76 & 195 & OSD \\
\hline $\mathrm{NC} / 28$ & \begin{tabular}{|l|}
2007 \\
\end{tabular} & Dikbosh & 10 & 0 & 0 & 0 & 0 & 0 & 10 & 2 & 3 & 3 & 8 & OSD \\
\hline $\mathrm{NC} / 29$ & 2008 & Dikbosh & 900 & 30 & 70 & 80 & \begin{tabular}{|l|}
470 \\
\end{tabular} & 0 & 1550 & 38 & 31 & 36 & 105 & \\
\hline
\end{tabular}

Source: Collated from records of Northern Cape and Skukuza State Veterinary Services, Department of Agriculture, Forestry and Fisheries, South Africa (by authors E.H. Dekker and T. Reardon)

FIGURE 6: Isolation spore counts for bone samples collected from various accessible parts of a carcass, as well as soil sampled from beneath the mouth, abdomen and head of carcasses from farms along the Northern Cape province, Ghaap Plateau, during the anthrax outbreaks of 2007-2008. The mean spore counts isolated from each bone type, soil location and farm area are indicated in colony forming units per gram. 


\begin{tabular}{|c|c|c|c|c|c|c|c|c|c|c|c|c|c|c|}
\hline \multirow[b]{3}{*}{ LAB.No } & \multirow[b]{3}{*}{ Year } & \multirow[b]{3}{*}{ Locality } & \multicolumn{7}{|c|}{ Spore Isolation Results from Bone Samples } & \multicolumn{5}{|c|}{ Spore Isolation Results from Soil Samples } \\
\hline & & & \multirow[b]{2}{*}{ 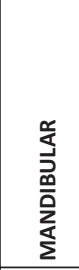 } & \multirow[b]{2}{*}{$\begin{array}{l}\text { 品 } \\
\text { 㟧 } \\
\text { 䍃 }\end{array}$} & \multirow[b]{2}{*}{$\frac{\varphi}{\widetilde{\alpha}}$} & \multirow[b]{2}{*}{$\stackrel{n}{\underline{z}}$} & \multirow[b]{2}{*}{$\sum_{\text {号 }}^{\stackrel{\infty}{\supset}}$} & \multirow[b]{2}{*}{ 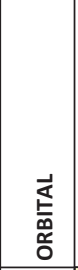 } & \multirow{2}{*}{ 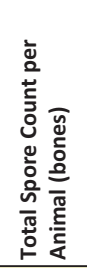 } & Mouth & Abdomen & Tail & \multirow{2}{*}{ 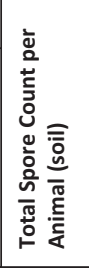 } & \multirow{2}{*}{ 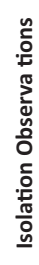 } \\
\hline & & & & & & & & & & $\times 10^{3} \mathrm{CFU} / \mathrm{g}$ & $\begin{array}{l}\times 10^{3} \\
\mathrm{CFU} / \mathrm{g}\end{array}$ & $\begin{array}{l}\times 10^{3} \\
\mathrm{CFU} / \mathrm{g}\end{array}$ & & \\
\hline \multicolumn{3}{|c|}{ Total Spore Count per Sample type on Dikbosch } & 5270 & 40 & 180 & 80 & 480 & 20 & 6070 & 187 & 324 & 300 & 811 & \\
\hline \multicolumn{3}{|c|}{ Average Spore Count per Sample Type on Dikbosch } & 878,3 & 6,7 & 30,0 & 13,3 & 80,0 & 3,3 & 1011,7 & 31,2 & 54,0 & 50,0 & 135,2 & \\
\hline \multicolumn{3}{|c|}{ Total Spore Count } & 91180 & 20010 & 26080 & 9510 & 14760 & 45050 & 199250 & 2786 & 1141,89 & 610 & 4537,89 & \\
\hline \multicolumn{3}{|c|}{ Mean Spore Count per Sample } & 3144,1 & 690,0 & $899, \beta$ & 327,9 & 509,0 & 1553,4 & 6870,7 & 96,1 & 39,4 & 21,0 & 156,5 & \\
\hline \multicolumn{3}{|c|}{$\begin{array}{l}\text { Proportion of Mean Spores Isolated per Sample } \\
\text { Type }\end{array}$} & $45,8 \%$ & $10,0 \%$ & $13,1 \%$ & $4,8 \%$ & $7,4 \%$ & $\mid 22,6 \%$ & & $61,4 \%$ & $25,2 \%$ & $13,4 \%$ & & \\
\hline \multicolumn{15}{|c|}{$\begin{array}{l}\mathrm{NOCl}-\mathrm{No} \text { Isolates obtained due to competitive } \\
\text { inhibition }\end{array}$} \\
\hline \multicolumn{15}{|c|}{ OSD- Obtained after serial dilution and passage } \\
\hline \multirow{2}{*}{\multicolumn{3}{|c|}{ OC -overgrown contaminant }} & & & $66,00 \%$ & & & & & & & & & \\
\hline & & & & $22 \%$ & & & $12 \%$ & & & & & & & \\
\hline
\end{tabular}

Source: Collated from records of Northern Cape and Skukuza State Veterinary Services, Department of Agriculture, Forestry and Fisheries, South Africa (by authors E.H. Dekker and T. Reardon)

FIGURE 6 (Continues...): Isolation spore counts for bone samples collected from various accessible parts of a carcass, as well as soil sampled from beneath the mouth, abdomen and head of carcasses from farms along the Northern Cape province, Ghaap Plateau during the anthrax outbreaks of 2007-2008. The mean spore counts isolated from each bone type, soil location and farm area are indicated in colony forming units per gram.

TABLE 3: Bacillus anthracis spore counts obtained from different isolation media from 1 gram of ground mandibular bones collected during the 2007-2008 anthrax outbreaks in the Northern Cape province, South Africa.

\begin{tabular}{lccc}
\hline Bone sample & *PET agar (2008) & *PET agar (2012) & **TSPBA (2012) \\
\hline $\mathrm{NC} / 14$ Mandible & 25500 & 18000 & Blood agar (2012) \\
NC/29Mandible & 900 & 550 & 26000 \\
\hline
\end{tabular}

*, Polymyxin EDTA thallous acetate; **, Trimethoprim sulphamethoxazole polymyxin blood agar.

louse flies evidencing activity. There is also a difference in B. anthracis yields between bone types and soil samples collected from the carcass sites during this outbreak. The mandibular bone yielded the highest spore counts and mean spore counts under the mouth or head of the carcass yielded the highest counts from soil. Control measures were taken during the 2008 anthrax outbreak seemed to reduce the spore counts as no $B$. anthracis could be isolated from the soil or bone from the carcass sites in 2012.

During the anthrax outbreaks of 2007-2008 in NCP, a disproportionate number of adult male kudus died from the disease. This is in keeping with studies in Etosha (Lindeque \& Turnbull 1994). This is notable because kudus are browsers and not dependent on as frequent water intake as their grazing counterparts. Kudu seemed to be the most susceptible species which died of anthrax, followed by zebra, impala and wildebeest, all of which except the kudu died on the game conservancies. The carcass distribution is not well represented because State Veterinary Services only intervened on the farms and not the national parks and nature conservancies where the disease is considered part of the natural ecology. On the other game farms, domestic animals and kudu died in greater numbers during the 20072008 anthrax outbreaks in NCP.
It has been consistently noted that spore counts in the soil appear to be dependent on the opening of a carcass and soil closest to these openings produce higher contagion concentrations (Dragon et al. 2005). This can be clearly seen for soil spore counts taken from under carcasses in Doringbult with the highest spore counts obtained from soil under the mouth of 2 female kudu carcasses (Figure 5 samples N/C04 and NC/05). Both of these carcasses had opened heads. The 2 carcasses did differ in spore counts obtained from soil under the abdomen where $\mathrm{NC} / 04$ had a noticeable hole in the abdomen while no such observation was made for NC/05. According to Bellan et al. (2013), the spore density at a carcass site is dependent on the vegetative cell concentration at host death coupled with the sporulation efficiency of the bacterium, spore survival and propensity for environmental replication. Sporulation is triggered by a paucity of nutrients coupled with exposure to oxygen (Koehler 2009; Minett \& Dhanda 1941; Sterne 1937; Turnbull 2008; Van Schaik, Prigent \& Fouet 2007). As such, soils contaminated by bacterial laden bodily fluids would contain more spores than an area a distance away from the carcass, which was observed by Dragon et al. (2005). The higher spore counts obtained from soil under the mouth of carcasses because of haemorrhagic discharge affirms the findings of Bellan et al. (2013), Dragon et al. (2005) and our study where high spore count were obtained from carcass 
heads opened by scavengers, thus providing extravasation fluid as enrichment media to the soil for possible vegetative bacterial amplification in the environment.

Statistically the mandible, ribs, orbital bone and vertebrae produced equivalent $B$. anthracis spore counts, although the mean spore counts demonstrated better isolation success rates from the mandibular, rib and orbital bones. In the NCP, crows are often observed to peck out the eyes of a carcass (HughJones \& De Vos 2002). Because of the lack of blood clotting (Leppla 1984) and the exposure of the haemorrhagic fluid in the orbital sockets to the elements; sporulation would be triggered along with increased contagion deposition in the environment. In KNP scavengers like vultures and hyeana are responsible for opening the carcass (Hugh-Jones \& De Vos 2002). Because of a lack or limiting numbers of scavengers in NCP, crows as well as scavengers like jackals and to a lesser extent hyena and leopards are responsible for opening the carcass.

Blowflies as well as louse flies have been observed on carcasses in NCP (Hugh-Jones \& De Vos 2002). Louse flies belong to the family Hippoboscidae and are blood-feeding flies. These flies although strong fliers, seldom fly more than a few metres, choosing instead to move to the next closest host when disturbed. They are abundant in the summer months and can be found clustered on the perineal and pubic regions as well as the neck and sides of the animal. They have a long standing association with anthrax transmission amongst cattle (Howell, Walker \& Nevill 1978). Cattle louse flies were observed on kudu carcasses at sites in Clearwater (Schmidtsdrif) and Dikbosch in NCP during the 2007-2008 outbreaks. The louse flies were easily collected from the kudu carcasses and an average of 200 spores were isolated from the head (mouthparts) of a louse fly. As a blood feeder, it has been suggested that this makes it a potential mechanical vector to its next animal host (De Vos \& Turnbull 2004; Howell et al. 1978). This however requires further study.

The ability of anthrax spores to persist in the earth for extended periods is because of specific soil and climatic conditions, which provide an environment conducive to its survival (De Vos \& Turnbull 2004; Smith et al. 2000). Soils rich in organic matter, ample in calcium, prone to alkalinity and with an ambient temperature above $15.5^{\circ} \mathrm{C}$ are considered optimal for persistence of spores. The exosporium of the spore is negatively charged (this charge and its strength are $\mathrm{pH}$ dependent) whereas humus particles are positively charged and are therefore able to chelate, which then provides environmental stability for the spores (Hugh-Jones \& Blackburn 2009). The spores can persist in soil and bone for decades or even centuries under such conditions (De Vos 1998; Wilson \& Russell 1964). These humus-spore clumps have the added advantage of being buoyant. During flooding, as was the case of the NCP 2007-2008 anthrax outbreaks, these clumps can be deposited or concentrated at water collection sites once the water evaporates, as the spores are highly resistant to UV radiation (Hugh-Jones \& Blackburn 2009; Hugh-Jones \& De Vos 2002; Vilas-Boas et al. 2007).

Many studies have evaluated the influencing factors on the dissemination and survival of $B$. anthracis that leads to outbreak trends. These include stocking rates, elevation, soil factors as mentioned above, water content and rainfall (Barro et al. 2016; Blackburn 2010; Chikerema et al. 2013; Joyner et al. 2010). Steenkamp (2013) elucidated the importance of the role of water and topography in the dissemination of anthrax in KNP along with various other studies (Pienaar 1960; Viljoen et al. 1928). The Ghaap is unique in its distribution of natural springs, Kimberlite pipes and dolomitic sinkholes which serve to flush the area with groundwater during periods of heavy rainfall and after groundwater recharge (Smit 1978). This theory is consistent with the high spore counts observed in water collection pans downhill from carcass sites during the 2007-2008 anthrax outbreaks.

It can be argued that $B$. anthracis survival in the soil and its subsequent exposure to inclement conditions could dilute the spores to a negligible detection limit (Smith et al. 2000), however, according to De Vos (1998) spores can remain stable in bone for decades if not centuries. The stable spore counts from the stored bone samples isolated in 2012 (Table 3) are an example of the spores endurance. The PET agar plates used in this study had spore counts equivalent to the TSPBA. The lack of B. anthracis spores from bone samples collected in 2012 reinforces the effectiveness of control measures employed during the 2007-2008 outbreaks. Because of the employment of a variety of control measures, the efficacy of the individual actions of using chlorine, formalin or the black sails or tarps cannot be determined, nor whether all the measures worked synergistically to reduce the inoculum in the environment. It is unclear to what extent the control measures of the 2007-2008 outbreaks managed to further stem the dissemination of spores through dilution in the environment. Bones treated at carcass sites were not a source of infection to animals suffering from pica in later seasons because they did not yield viable spores which could pose a threat of infection (De Vos 1998; De Vos \& Turnbull 2004).

The reduction of inoculum in the environment and the corresponding reduced spore exposure is paramount in the control of anthrax (De Vos \& Turnbull 2004; Turnbull 2008; Watson \& Keir 1994). This was indicated when 2012 isolations from the reference bone samples collected during the outbreak (used as positive controls) had spore counts similar to those enumerated at the time of collection.

\section{Conclusion}

There are too many variables at each carcass site that could possibly influence the dissemination of anthrax which serves to complicate our understanding of the disease as seen with the 2007-2008 anthrax outbreaks in NCP. Modelling which includes all the factors (host, bacterium, vectors and environment) will provide more insight into the unique ecology of anthrax on the Ghaap Plateau. 
Carcass bones are a reliable source for the successful isolation of $B$. anthracis. The mandibular and orbital bones as well as soil beneath the head of a carcass proved to be a prodigious source of viable $B$. anthracis spores from carcasses collected during the 2007-2008 NCP outbreaks

The control measures of burning or spraying carcasses with chlorine or formalin and then covering them with tarp or plastic were applied by farmers on the recommendation of the veterinary services during the 2007-2008 outbreaks. As no spores could be isolated in 2012 from the same sites and bones remaining in the environment, this finding indicates that these control measures had greatly reduced or possibly even eliminated the inoculum at the treated carcass sites.

\section{Acknowledgements}

We offer our sincere thanks to the farmers of the Northern Cape for their hospitality and wholehearted co-operation; such studies would not be possible without you. Thanks are also due to all the State Veterinary Services staff involved for their efforts and data contributions as well as the Northern Cape Provincial Government for allowing us to conduct this study. The authors would like to acknowledge and thank the National Research Foundation (NRF) for funding this study.

\section{Competing interests}

The authors declare that they have no financial or personal relationships that may have inappropriately influenced them in writing this article.

\section{Authors' contributions}

A.H. was responsible for experimental work, data capture and data analysis. E.H.D. generated field data in 2008 and facilitated field survey data collection in 2012. T.R. generated field data in 2008. C.B. performed statistical analyses and data vetting. H.v.H. was the project leader and obtained legal permissions.

\section{References}

Barro, A.S., Fegan, M., Moloney, B., Porter, K., Muller, J., Warner, S. et al., 2016 'Redefining the Australian anthrax belt: Modeling the ecological niche and predicting the geographic distribution of Bacillus anthracis,' PLOS Neglected Tropical Diseases 10, e0004689. https://doi.org/10.1371/journal.pntd.0004689

Bellan, S.E., Turnbull, P.C., Beyer, W. \& Getz, W.M., 2013, 'Effects of experimental exclusion of scavengers from carcasses of anthrax-infected herbivores on Bacillus anthracis sporulation, survival, and distribution', Applied and Environmental Microbiology 79, 3756-3761. https://doi.org/10.1128/AEM.00181-13

Bengis, R., Kock, R. \& Fischer, J., 2002, Infectious animal diseases: The wildlife/ livestock interface', Revue Scientifique et Technique-Office International des épizooties 21, 53-66.

Blackburn, J.K., 2010, 'Integrating geographic information systems and ecological niche modeling into disease ecology: A case study of Bacillus anthracis in the United States and Mexico', Emerging and Endemic Pathogens 1, 59-88. https:// doi.org/10.1007/978-90-481-9637-1_7

Blackburn, J.K., Van Ert, M., Mullins, J.C., Hadfield, T.L. \& Hugh-Jones, M.E., 2014, 'The necrophagous fly anthrax transmission pathway: Empirical and genetic evidence from wildlife epizootics', Vector Borne Zoonotic Diseases 14, 576-583. https://doi. org/10.1089/vbz.2013.1538

Boyazoglu, P.A., 1973, Mineral imbalances of ruminants in Southern Africa, SASAP Annual Congress, South Africa.

Braack, L.E. \& De Vos, V., 1990, 'Feeding habits and flight range of blow-flies (Chrysomyia spp.) in relation to anthrax transmission in the Kruger National Park South Africa', The Onderstepoort Journal of Veterinary Research 57, 141-142.
Chikerema, S.M., Murwira, A., Matope, G. \& Pfukenyi, D.M., 2013, 'Spatial modelling of Bacillus anthracis ecological niche in Zimbabwe', Preventive Veterinary Medicine 111, 25-30. https://doi.org/10.1016/j.prevetmed.2013.04.006

De Vos, V., 1990, 'The ecology of anthrax in the Kruger National Park, South Africa', Salisbury Medical Bulletin 68, 19-23.

De Vos, V., 1998, 'The isolation of viable and pathogenic Bacillus anthracis from 200-year-old bone fragments from the Kruger National Park', ARC-Onderstepoort OIE International Congress with WHO Co-sponsorship on Anthrax, Brucellosis, CBPP, Clostridial and Mycobacterial Diseases, Berg-en Dal, Kruger National Park, Sigma Press, August 09-15, 1998, pp. 22-24.

De Vos, V. \& Turnbull, P.C.B., 2004, 'Anthrax', in J.A.W. Coetzer, \& R.C. Tustin (eds.) Infectious Diseases of Livestock, 3rd edn., vol. 3, pp. 1788-1818, Oxford University Press, Cape Town, South Africa.

Dragon, D.C., Bader, D.E., Mitchell, J. \& Woollen, N., 2005, 'Natural dissemination of Bacillus anthracis spores in northern Canada', Applied and Environmental Microbiology 71, 1610-1615. https://doi.org/10.1128/AEM.71.3.1610-1615.2005

Edmonds, C.R., 1922, Diseases of Animals in South Africa, vol. 2, Ballière, Tindall \& Cox, London, pp. 97-174.

Fourie, J.H. \& Roberts, B.R., 1973, 'A comparative study of three veld types of the Northern Cape: Species evaluation and yield', African Journal of Range and Forage Science 11, 79-85.

Gilfoyle, D., 2006, 'Anthrax in South Africa: Economics, experiment and the mass vaccination of animals, c. 1910-1945', Medical History 50, 465-490.

Howell, C.J., Walker, J.B. \& Nevill, E.M., 1978, Ticks, mites and insects infesting domestic animals in South Africa, Science Bulletin, Republic of South Africa.

Hugh-Jones, M. \& Blackburn, J., 2009, 'The ecology of Bacillus anthracis', Molecular Aspects of Medicine 30, 356-367. https://doi.org/10.1016/j.mam.2009.08.003

Hugh-Jones, M.E. \& De Vos, V., 2002, 'Anthrax and wildlife,' Revue Scientifique et Technique 21, 359-383. https://doi.org/10.20506/rst.21.2.1336

Joyner, T.A., Lukhnova, L., Pazilov, Y., Temiralyeva, G., Hugh-Jones, M.E., Aikimbayev, A. et al., 2010, 'Modeling the potential distribution of Bacillus anthracis under multiple climate change scenarios for Kazakhstan', PLoS One 5, e9596. https://doi. org/10.1371/journal.pone.0009596

Knisely, R.F., 1966, 'Selective medium for Bacillus anthracis', Journal of Bacteriology 92, 784-786, viewed 14 August 2014, from http://pubmedcentralcanada.ca/ pmcc/articles/PMC276323/pdf/jbacter00415-0290.pdf

Koehler, T.M., 2009, Bacillus anthracis physiology and genetics', Molecular Aspects of Medicine 30, 386-396. https://doi.org/10.1016/j.mam.2009.07.004

Kriek, N. \& Odendaal, M., 1994, 'Botulism', in J.A.W. Coetzer, G.R. Thomson \& R.C. Tuston (eds.), Infectious diseases of livestock, vol. 2, pp. 1354-1371, Oxford Press, Cape Town.

Leppla, S.H., 1984, 'Bacillus anthracis calmodulin-dependent adenylate cyclase: Chemical and enzymatic properties and interactions with eucaryotic cells', Advances in Cyclic Nucleotide Protein Phosphorylation Research 17, 189-198.

Lindeque, P.M. \& Turnbull, P.C., 1994, 'Ecology and epidemiology of anthrax in the Etosha National Park, Namibia', The Onderstepoort Journal of Veterinary Research 61, 71-83.

Minett, F. \& Dhanda, M., 1941, 'Multiplication of B. anthracis and Cl. chauvei in soil and water', Indian Journal of Veterinary Science and Animal Husbandry 11, 308328.

Nduli, N., 2009, Department of Agriculture 2008/09 Annual Report, Directorate Agricultural Information Services, South Africa.

Partridge, T.C., Dollar, E.S.J., Moolman, J. \& Dollar, L.H., 2010, 'The geomorphic provinces of South Africa, Lesotho and Swaziland: A physiographic subdivision for earth and environmental scientists', Transactions of the Royal Society of South earth and environmental scientists', Transactions of the Royal
Africa 65, 1-47. https://doi.org/10.1080/00359191003652033

Pienaar, U.D., 1967, 'Epidemiology of anthrax in wild animals and the control of anthrax epizootics in the Kruger National Park, South Africa', Federation Proceedings 26, 1496-1502.

Pienaar, U.D.V., 1960, 'N uitbraak van Miltsiekte onder wild in die Nasionale Krugerwildtuin', Koedoe 3, 238-251.

Smit, P., 1978, 'Groundwater recharge in the dolomite of the Ghaap Plateau nea Kuruman in the Northern Cape, Republic of South Africa', Water SA, 4, 81-92.

Smith, K.L., Devos, V., Bryden, H., Price, L.B., Hugh-Jones, M.E. \& Keim, P., 2000 'Bacillus anthracis diversity in Kruger National Park', Journal of Clinical Microbiology 38, 3780-3784.

Steenkamp, J.P., 2013, Ecological Suitability Modelling for Anthrax in the Kruger National Park, South Africa MVetMed, University of Pretoria, viewed 18 December 2015, from http://repository.up.ac.za/handle/2263/23358

Sterne, M., 1937, 'The effects of different carbon dioxide concentrations on the growth of virulent anthrax strains: Pathogenicity and immunity tests on Guineapigs and sheep with anthrax variants derived from virulent strains', Onderstepoort Journal of Veterinary Science 9, 49-67.

Theiler, A., 1912, Facts and theories about stijfziekte and lamziekte, Director of Veterinary Research, South Africa.

Theiler, A., 1927, Lamsiekte (Parabotulism) in Cattle in South Africa, 11th \& 12th Report, Director Veterinary Education \& Research, Union South Africa, pp. 8211361.

Turnbull, P.C., 1999, 'Definitive identification of Bacillus anthracis - A review', Journal of Applied Microbiology 87, 237-40. https://doi.org/10.1046/j.1365-2672. 1999.00876.x 
Turnbull, P.C.B., 2008, Anthrax in humans and animals, World Health Organization, viewed 12 November 2010, from http://www.who.int/csr/resources/publications/ AnthraxGuidelines2008/en/

Van Der Lugt, J., De Wet, S., Bastianello, S., Kellerman, T. \& Van Jaarsveld, L., 1995 'Two outbreaks of type C and type D botulism in sheep and goats in South Africa', Journal-South African Veterinary Association 66, 77-77.

Van Schaik, W., Prigent, J. \& Fouet, A., 2007, The stringent response of Bacillus anthracis contributes to sporulation but not to virulence', Microbiology 153 4234-4239. https://doi.org/10.1099/mic.0.2007/010355-0

Vilas-Boas, G., Peruca, A. \& Arantes, O., 2007, 'Biology and taxonomy of Bacillus cereus, Bacillus anthracis, and Bacillus thuringiensis', Canadian Journal of Microbiology 53, 673-687. https://doi.org/10.1139/W07-029

Viljoen, P.R., Curson, H.H. \& Fourie, P.J.J., 1928, 'Anthrax in South Africa', in With special reference to improved methods of protective inoculation, 13th and 14th edn., Director of Veterinary Education and Research, viewed 06 January 2015 , from http://hdl.handle.net/2263/13679
Visagie, N., 2008, Huge anthrax outbreak hits farms, iOL News, viewed 12 June 2009, from http://www.iol.co.za/news/south-africa/huge-anthrax-outbreak-hits-farmsfrom http://Www.iol.co.za

Watson, A. \& Keir, D., 1994, 'Information on which to base assessments of risk from environments contaminated with anthrax spores', Epidemiology and Infection 113, 479-490. https://doi.org/10.1017/S0950268800068497

Williams, E.S. \& Barker, I.K., 2008, Infectious diseases of wild mammals, 3rd edn., vol. 2, pp. 396-412, John Wiley \& Sons, viewed n.d., from http://eu.wiley.com/ WileyCDA/WileyTitle/productCd-0813825563.html

Williams, H. \& Richardson, A., 1984, 'Growth energetics in relation to temperature for larvae of four species of necrophagous flies (Diptera: Calliphoridae)', Australian Journal of Ecology 9, 141-152. https://doi.org/10.1111/j.1442-9993.1984. tb01352.x

Wilson, J.B. \& Russell, K.E., 1964, 'Isolation of Bacillus anthracis from soil stored 60 years', Journal of Bacteriology 87, 237-238.

Appendix starts on the next page $\rightarrow$ 


\section{Appendix 1}

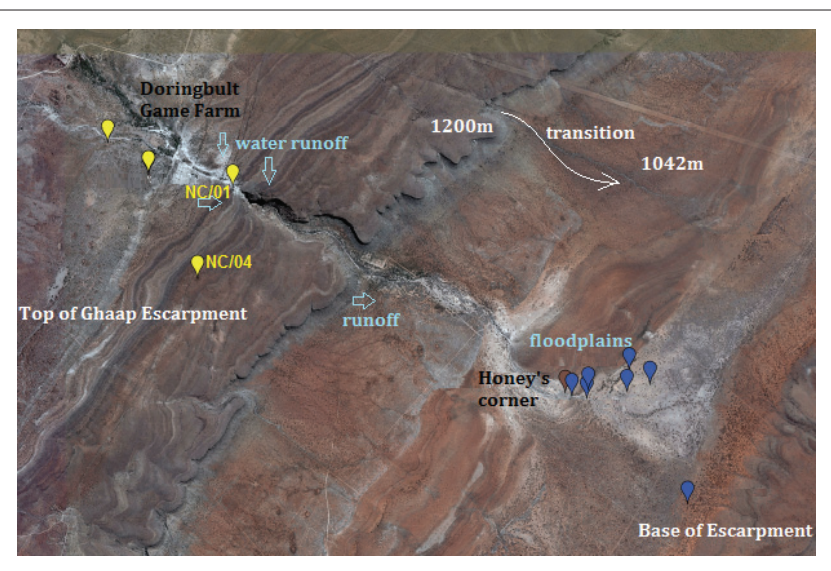

Source: Generated in Google earth V 6.2.2.6613 (http://www.earth.google.com) using data collected during this study

Note: Soil samples were collected in 2012 from farms and carcass sites identified as anthrax positive by farmers and State Veterinary Services in 2008. Additional soil samples were taken along water runoff paths following the Ghaap escarpment drainage topography.

FIGURE 1-A1: A closer view of water drainage on Doringbult and Honey's Corner farms in the Ghaap Plateau in the Northern Cape province. The water runof moves towards Doringbult and thereafter to Honey's corner farm where mass alluvial deposition occurs (white areas).

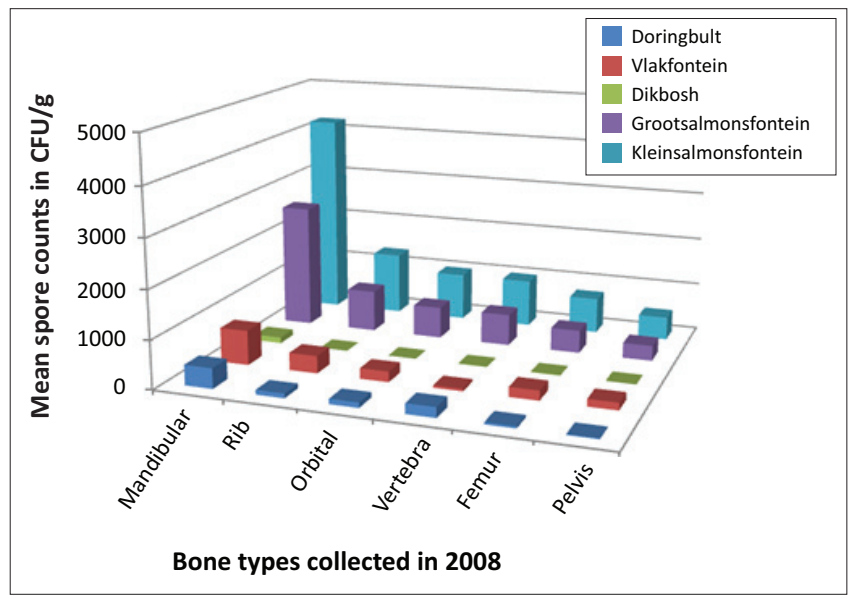

FIGURE 2-A1: The mean Bacillus anthracis spore counts (in colony forming units per gram) obtained from different bones types in the same carcass on farms afflicted with anthrax in 2008, Northern Cape, South Africa.

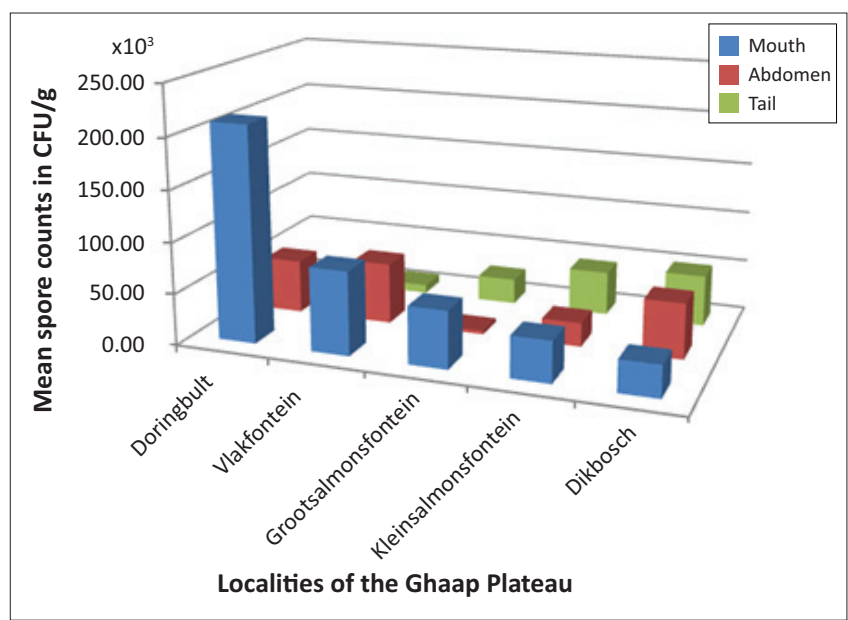

FIGURE 3-A1: Mean Bacillus anthracis spore counts in colony forming units per gram obtained from soil under different parts of anthrax-positive carcasses on farms on the Ghaap Plateau during an outbreak in 2008, Northern Cape, South Africa. 